\title{
Importance of Soft Skills for Education and Career Success
}

\author{
Shaheen Majid, Zhang Liming, Shen Tong, Siti Raihana \\ Nanyang Technological University, Singapore
}

\begin{abstract}
Appropriate soft skills play an important role in a successful career as well as during social interactions in the society. These skills are also highly sought after by employers recruiting fresh graduates. The main purpose of this study was to investigate students' perceptions of the importance of soft skills for their education and employment. A questionnaire was used for data collection and 188 undergraduate business management students from four universities in Singapore participated in this study. It was found that a majority of the respondents felt that soft skills were useful for social interaction as well as for career advancement. However, they did not think that these skills contribute considerably to their academic performance. The top five important soft skills identified by the students were: teamwork and collaboration, decision-making, problem-solving, time management and critical thinking skills. This paper suggests certain measures for improving soft skills of students which may also help improve their employment perspectives.
\end{abstract}

\section{Introduction}

Due to a variety of factors, today's business environment is becoming more complex, uncertain and competitive. All types of organizations consider human resources as their key asset, which plays a critical role in organizational performance and success. Most employers are likely to hire, retain and promote persons who are dependable, resourceful, ethical, having effective communication, self directed, willing to work and learn, and having positive attitude [1]. Employers usually prefer to see a fine blend of competencies in their staff and, in addition to discipline-based knowledge and skills, adequate levels of soft skills are considered desirable for moving forward in the career [2]. They feel professional and technical skills alone cannot help achieve organizational goals and objectives. It is because their staff will also be involved in different levels of leadership and decision-making activities. Employees also need to communicate effectively within the organization, with their customers and other stakeholders.
Basically, soft skills refer to personalities, attributes, qualities and personal behaviour of individuals. Soft skills include certain abilities such as communication, problem-solving, self-motivation, decision-making, and time management skills [3]. A study by Hodges and Burchell [4] investigated the perceptions of business employers of the importance of different skills. It was reported that eight out of top ten skills were soft skills which included the ability and willingness to learn, teamwork and cooperation, interpersonal communication, energy and passion, and problem-solving skills. A study covering over 52 different professions with more than 8,000 managers in the United States identified soft skills of employees as the major competency in nearly all the professions, even in the technical environments [5].

While it is now a well-established fact that employers are increasingly putting more emphasis on soft skills, it is equally important that students should also adequately appreciate the value of such skills and make deliberate efforts to acquire them. Porter [6] reported that many business students do not put much value to developing soft skills. Probably that is why, as suggested by Rynes et al [7], the business students' attitude towards behavioural courses, with substantial coverage given to soft skills development, is usually negative together with their reluctance to register for such courses. As a result, there is an awareness gap resulting in deficiency of soft skills among business graduates entering the work force.

Consequently, there is now more pressure on academic institutions to enhance soft skills of their students. Kumara and Sahasranam [8] used a core soft skills inventory test to investigate soft skills of engineering students in India. They reported that, with well-planned training programs, it is possible to tune, shape and develop creativity and soft skills among all students. Addams et al [9] believed the communication skills of business students, particularly for writing persuasive business letters, can be improved by designing assignments using real-life organizations and scenarios. Alshare, Lane and Miller [10] studied perceptions of students and faculty of the adequacy of soft skills in information systems curricula in different universities in the USA. It was reported that generally students were more satisfied than faculty about the coverage of soft skills. Realizing the importance of soft skills, several studies 
have also emphasised the point that these skills should be embedded in the curriculum, thus making it easier for students to acquire them [11, 12].

The literature review suggests that a majority of the studies on this topic have been done from employers' perspective and only a limited number of studies have focused on the perceptions and attitudes of students towards soft skills. In addition, a higher percentage of such studies were conducted in North America and Europe with different learning environment and work culture then in many Asian countries. It is, therefore, worth exploring students' perceptions of soft skills from a new angle and context. The main objective of this study was to investigate the perceptions of business management students of the importance of soft skills for their education and employment. Some areas covered by this study were: students' perceptions of the value of soft skills, self-efficacy of the level of skills possessed by them, skills needing further improvement, participation in skill development programs, and the role of academic institutions in developing soft skills.

\section{Methodology}

A questionnaire was used to collect data from undergraduate business management students from four universities in Singapore, i.e. Nanyang Technological University (NTU), National University of Singapore (NUS), Singapore Management University (SMU), and Singapore Institute of Management (SIM). The questionnaire was mainly consisted of multiple choice and rating scale matrix questions to solicit responses. Most of the questions were close-ended, however wherever needed, the respondents were provided with the flexibility to make comments or provide additional information. The ethics approval of the study was obtained from the Institutional Review Board (IRB) of the University.

The survey participants were selected through the convenience sampling technique. Business management undergraduate students at the four selected universities were approached with an oral request to participate in this study. A copy of questionnaire was provided to those students who expressed their willingness to participate. The survey lasted for two weeks in the second quarter of 2011, and a total of 188 students participated in this study.

\section{Findings}

The following sections provide data analysis and findings of the survey.

\subsection{Respondents' profile}

A comparable number of participants from the four universities participated in this study: SIM (51), NTU (50), SMU (49), and NUS (44). Six respondents did not fully complete the questionnaire; therefore, the data analysis is based on 188 completely filled-in survey forms. The percentage of Singaporean and overseas students was $67.6 \%$ and $32.4 \%$ respectively. The overseas students were mainly from China, India, Malaysia, Indonesia, Brunei, Thailand and the Philippines. In terms of gender, more female respondents took part $(57.8 \%)$ than their male counterparts $(42.2 \%)$. As for the year of study, there were 72 respondents $(38.3 \%)$ in their second year of study and it was the largest group, while $41(21.8 \%)$ were in first year, $52(27.7 \%)$ in third year and only $18(9.6 \%)$ were in their fourth year of study. Five students did not indicate their year of study.

\subsection{Awareness of soft skills}

The participating students were asked what skills, in their opinion, can be categorized as soft skills. The purpose was to investigate if they have a clear understanding of soft skills. Based on literature review, a list of 14 skills was developed. Out of the 188 respondents, less than $40(21.3 \%)$ students chose all the skills, which reflects their limited understanding of soft skills. The top four soft skills, as identified by the students, were communication, leadership, persuasion and negotiation skills (see Table 1).

Table 1. Skills considered as soft skills by the respondents (multiple responses)

\begin{tabular}{|c|l|c|}
\hline Ranking & \multicolumn{1}{|c|}{ Soft Skills } & $\begin{array}{c}\text { Frequency } \\
(\mathbf{n = 1 8 8})\end{array}$ \\
\hline 1 & Communication skills & 147 \\
\hline 2 & Leadership skills & 118 \\
\hline 3 & Persuasion skills & 112 \\
\hline 4 & Negotiation skills & 107 \\
\hline 5 & Conflict management & 91 \\
\hline 6 & Time management & 74 \\
\hline 7 & Problem solving & 71 \\
\hline 8 & Teamwork spirit & 70 \\
\hline 9 & Creative problem solving & 70 \\
\hline 10 & Personal effectiveness & 62 \\
\hline 11 & Strategic thinking & 61 \\
\hline 12 & Positive work attitude & 54 \\
\hline 13 & Willingness to learn & 48 \\
\hline 14 & Passion towards work & 42 \\
\hline
\end{tabular}

Some of the personality attributes such as positive work attitude, willingness to learn and passion towards work were not regarded as soft skills by a majority of the students. Other soft skills 
suggested by the students, not included in the questionnaire, were 'project management skills', 'saying no to inappropriate requests/suggestions' and 'know when/where to stop arguments'.

\subsection{Perceived importance of soft skills}

A set of statements were used to investigate students' overall perceptions of the importance of soft skills. A majority of the students either agreed or strongly agreed with the statements that soft skills were very important for career advancement, highly sought after by employers, and for getting a better job (see Table 2). Similarly, $103(55.1 \%)$ of the respondents agreed with the suggestion that soft skills are difficult to learn compared to professional knowledge and skills.

On the contrary, a majority of the respondents either disagreed or strongly disagreed with the statements that soft skills cannot be enhanced through practice and that these skills were not as important as professional knowledge and skills. This indicates that students have a good understanding of the important and value of soft skills.

Table 2. General perceptions of soft skills $(n=187)$

\begin{tabular}{|l|c|c|c|c|c|}
\hline \multicolumn{1}{|c|}{ Statement } & SD & D & N & A & SA \\
\hline $\begin{array}{l}\text { Soft skills are critical for } \\
\text { career advancement }\end{array}$ & 6 & 7 & 39 & $\mathbf{8 3}$ & 52 \\
\hline $\begin{array}{l}\text { Soft skills are highly } \\
\text { sought after by employers }\end{array}$ & 5 & 7 & 52 & $\mathbf{8 9}$ & 34 \\
\hline $\begin{array}{l}\text { Soft skills are important for } \\
\text { getting a better job }\end{array}$ & 5 & 8 & 48 & $\mathbf{9 5}$ & 31 \\
\hline $\begin{array}{l}\text { Soft skills are difficult to } \\
\text { learn compared to } \\
\text { professional knowledge }\end{array}$ & 5 & 31 & 48 & $\mathbf{8 3}$ & 20 \\
\hline $\begin{array}{l}\text { Soft skills cannot be } \\
\text { enhanced through practice }\end{array}$ & 25 & $\mathbf{8 1}$ & 47 & 28 & 6 \\
\hline $\begin{array}{l}\text { Soft skills are not as } \\
\text { important as professional } \\
\text { knowledge }\end{array}$ & $\mathbf{4 8}$ & $\mathbf{5 6}$ & 38 & 33 & 12 \\
\hline
\end{tabular}

SD: strongly disagree, D: disagree, N: neutral, A: agree, SA: strongly agree

Students were also asked to rate the importance of soft skills for different purposes, using a 7-point semantic differential scale. As shown in Table 3, soft skills were considered the most important for 'getting along with people' (mean score 5.70), followed by 'career advancement' (mean score 5.46). However, the students felt that such skills were comparatively less important for their academic performance.
Table 3. Importance of soft skills

\begin{tabular}{|l|c|c|c|}
\hline \multicolumn{1}{|c|}{ Purpose } & n & $\begin{array}{c}\text { Mean } \\
(\mathbf{1} \sim 7)\end{array}$ & SD \\
\hline Getting along with people & 188 & 5.70 & 1.46 \\
\hline Career advancement & 188 & 5.46 & 1.69 \\
\hline Finding a job & 188 & 5.07 & 1.64 \\
\hline Academic performance & 188 & 4.29 & 1.82 \\
\hline
\end{tabular}

To further corroborate students' perceptions of the importance of soft skills, they were asked to rate the relative importance of a set of 14 skills, derived from previous studies, for the purpose of employment. The five top skills were: leadership, teamwork, decision-making, problem solving, and time management (see Table 4).

Table 4. Importance of soft skills for employment

\begin{tabular}{|l|c|c|c|}
\hline \multicolumn{1}{|c|}{ Soft Skills } & n & $\begin{array}{c}\text { Mean } \\
(\mathbf{1} 7)\end{array}$ & SD \\
\hline Leadership & 187 & $\mathbf{5 . 5 3}$ & 1.35 \\
\hline Teamwork and collaboration & 187 & $\mathbf{5 . 4 7}$ & 1.28 \\
\hline Decision-making & 187 & $\mathbf{5 . 4 3}$ & 1.43 \\
\hline Problem-solving & 186 & $\mathbf{5 . 3 8}$ & 1.39 \\
\hline Time management & 187 & $\mathbf{5 . 3 4}$ & 1.36 \\
\hline Passion and optimism & 187 & 5.29 & 1.25 \\
\hline Critical thinking skills & 183 & 5.27 & 1.45 \\
\hline Willingness to learn & 187 & 5.26 & 1.37 \\
\hline Self-motivation and self-direction & 186 & 5.16 & 1.40 \\
\hline Making presentations & 187 & $\mathbf{5 . 0 5}$ & 1.74 \\
\hline Small group discussions & 187 & $\mathbf{5 . 0 0}$ & 1.50 \\
\hline Writing business communications & 187 & $\mathbf{4 . 9 1}$ & 1.32 \\
\hline Writing proposals & 187 & $\mathbf{4 . 6 8}$ & 1.29 \\
\hline Writing memoranda & 186 & $\mathbf{4 . 6 2}$ & 1.24 \\
\hline
\end{tabular}

It was a matter of concern that five communication-related soft skills were perceived to be the least important for seeking employment. It was particularly puzzling as earlier the highest number (147 or $78.2 \%$ ) of the respondents categorized it as a soft skill. It means although they consider communication-related skills as part of soft skills, they do not think these skills are important in seeking employment despite the fact that they need to prepare their job applications and appear for interviews.

\subsection{Importance of soft skills for different professions}

The students were asked to indicate the importance of soft skills for different business related professions. Students felt that soft skills were more important for those jobs where business professionals need to frequently communicate and interact with 
customers and other stakeholders, such job positions as marketing executives, sales personnel and insurance consultants (see Table 5). On the contrary, they felt that professionals involved in back office jobs such as financial analysts, auditors, and accounts, need comparatively lesser levels of soft skills. Although business professionals engaged in such jobs probably less frequently communicate with external customers, they still need good soft skills to effectively discharge their responsibilities within the organization.

Table 5. Level of soft skills required by different category of professionals $(n=188)$

\begin{tabular}{|l|c|c|}
\hline \multicolumn{1}{|c|}{ Profession } & $\begin{array}{c}\text { Mean } \\
(\mathbf{1 ~ 7 ) ~}\end{array}$ & SD \\
\hline Marketing Executives & $\mathbf{5 . 8 6}$ & $\mathbf{1 . 2 1}$ \\
\hline Sales Personnel & $\mathbf{5 . 7 4}$ & $\mathbf{1 . 4 0}$ \\
\hline Insurance Service Consultants & $\mathbf{5 . 7 2}$ & $\mathbf{1 . 3 0}$ \\
\hline Media \& Advertising Executives & $\mathbf{5 . 7 2}$ & $\mathbf{1 . 3 0}$ \\
\hline Corporate Communications Officers & 5.66 & 1.37 \\
\hline Human Resource Officers & 5.64 & 1.39 \\
\hline Project Management Executives & 5.57 & 1.36 \\
\hline Financial Service Consultants & 5.32 & 1.31 \\
\hline Business Administrators & 4.99 & 1.47 \\
\hline Stock Brokers & 4.98 & 1.56 \\
\hline Bank Executives & 4.88 & 1.57 \\
\hline Financial Analysts & 4.79 & 1.19 \\
\hline Auditors & $\mathbf{4 . 1 9}$ & $\mathbf{1 . 5 0}$ \\
\hline Accountants & $\mathbf{3 . 7 8}$ & $\mathbf{1 . 5 6}$ \\
\hline
\end{tabular}

\subsection{Students' perception of the level of soft skills possessed by them}

The students were asked about their selfassessment of the level of soft skills possessed by them. The top five soft skills, as claimed by the students were: willingness to learn, teamwork, passion and optimism, time management, and selfmotivation and self-direction (see Table 6).

Table 6. Self-assessment of the level of soft skills possessed by the respondents $(n=188)$

\begin{tabular}{|l|c|c|}
\hline \multicolumn{1}{|c|}{ Soft Skills } & $\begin{array}{c}\text { Mean } \\
(\mathbf{1 ~ 7 )}\end{array}$ & SD \\
\hline Willingness to learn & $\mathbf{5 . 3 2}$ & 1.29 \\
\hline Teamwork and collaboration & $\mathbf{5 . 3 2}$ & 1.26 \\
\hline Passion and optimism & $\mathbf{5 . 0 5}$ & 1.19 \\
\hline Time management & $\mathbf{5 . 0 1}$ & 1.33 \\
\hline Self-motivation and self-direction & 4.95 & 1.23 \\
\hline Decision-making & 4.95 & 1.22 \\
\hline Problem-solving & 4.94 & 1.21 \\
\hline Leadership & 4.90 & 1.33 \\
\hline Critical thinking skills & 4.90 & 1.37 \\
\hline Small group discussions & $\mathbf{4 . 8 7}$ & 1.27 \\
\hline Writing proposals & $\mathbf{4 . 6 4}$ & 1.17 \\
\hline Making presentations & $\mathbf{4 . 6 3}$ & 1.44 \\
\hline Writing business communications & $\mathbf{4 . 5 6}$ & 1.27 \\
\hline Writing memoranda & $\mathbf{4 . 4 3}$ & 1.25 \\
\hline
\end{tabular}

Once again, bottom five skills were related to communication which means students think that they do not possess adequate levels of communication skills.

The correlation analysis showed a strong relationship between the perceived importance of the majority of soft skills and the level of these skills possessed by the students (see Table 7). In other words, students scored better for those skills which they perceived to be important. It is likely they were making efforts to improve those skills that they considered important. As most of the communication related skills were considered less important for career development, there is a need that academic institutions should create awareness among students about the importance of such skills in seeking employment and undertaking work related activities.

Table 7. Correlation between perceived importance and skills level

\begin{tabular}{|c|c|}
\hline Soft Skills & Correlation \\
\hline Willingness to learn & $.395\left({ }^{* *}\right)$ \\
\hline Teamwork and cooperation & $.384\left({ }^{\star \star}\right)$ \\
\hline Passion and optimism & $.355\left({ }^{\star *}\right)$ \\
\hline Time management & $.231\left(^{\star *}\right)$ \\
\hline Self-motivation and self-direction & $.416\left(^{\star \star}\right)$ \\
\hline Decision-making & $.244\left(^{* *}\right)$ \\
\hline Problem-solving & $.235\left({ }^{* *}\right)$ \\
\hline Leadership & $.186\left(^{*}\right)$ \\
\hline Critical thinking skills & $.305\left(^{\star \star}\right)$ \\
\hline Small group discussions & $.524\left(^{* *}\right)$ \\
\hline Writing proposals & .121 \\
\hline Making presentations & $.529\left({ }^{* *}\right)$ \\
\hline Writing business communications & $.184\left(^{\star}\right)$ \\
\hline Writing memoranda & $.259\left(^{\star *}\right)$ \\
\hline
\end{tabular}

** Correlation is significant at the 0.01 level (2-tailed)

* Correlation is significant at the 0.05 level (2-tailed).

\subsection{Desire for improving soft skills}

The respondents were asked to choose what soft skills they would like to improve. The top two soft skills that students wanted to improve were leadership and communication skills (see Table 8). Earlier these skills were also picked as the two most important soft skills (see Table 1). However, it was interesting to note that when communication skills were divided into more specific communication skills (see Table 4), these skills received the lowest ranking. It appeared there were some misperceptions among the students about the scope of different communication skills. 
Table 8. Soft skills needing improvement (multiple responses)

\begin{tabular}{|l|l|c|}
\hline Ranking & \multicolumn{1}{|c|}{ Soft Skills } & $\begin{array}{c}\text { Frequency } \\
(\mathbf{n = 1 8 8})\end{array}$ \\
\hline 1 & Leadership skills & $\mathbf{8 8}$ \\
\hline 2 & Communication skills & $\mathbf{8 7}$ \\
\hline 3 & Persuasion skills & $\mathbf{8 3}$ \\
\hline 4 & Negotiation skills & $\mathbf{8 0}$ \\
\hline 5 & Conflict resolution & 79 \\
\hline 6 & Time management & 71 \\
\hline 7 & Strategic thinking & 68 \\
\hline 8 & Problem solving & 63 \\
\hline 9 & Personal effectiveness & 62 \\
\hline $9($ tied) & Creative problem solving & 62 \\
\hline 11 & Positive work attitude & 39 \\
\hline 12 & Willingness to learn & 38 \\
\hline 13 & Teamwork spirit & 35 \\
\hline 14 & Passion towards work & 34 \\
\hline
\end{tabular}

The next two soft skills that students wanted to improve were persuasion and negotiation skills. Four soft skills that only $20 \%$ or fewer students wanted to improve were positive work attitude, willingness to learn, teamwork spirit, and passion towards work. It was probably because earlier only a very small number of the students considered these skills as part of soft skills (see Table 1).

\subsection{Barrier to developing and practicing communication skills}

As many previous studies suggest that a majority of the students lack adequate communication skills, students participating in this study were asked about the barriers encountered by them in developing and practicing different communication skills. The top four barriers, as identified by the students, were: lack of confidence, nervousness, shyness, and lack of proper training (see Table 9).

Table 9. Barriers to practicing communication skills $(n=188)$

\begin{tabular}{|c|l|c|}
\hline & \multicolumn{1}{|c|}{ Barriers } & Frequency \\
\hline 1 & Lack of confidence & $\mathbf{8 9}$ \\
\hline 2 & Nervousness & $\mathbf{8 8}$ \\
\hline 3 & Shyness & $\mathbf{5 9}$ \\
\hline 4 & Lack of proper training & $\mathbf{5 8}$ \\
\hline 5 & Non-encouraging environment & 51 \\
\hline 6 & Language deficiency & 48 \\
\hline 7 & Lack of knowledge & 47 \\
\hline 8 & Cultural barriers & $\mathbf{3 8}$ \\
\hline
\end{tabular}

Although around one-third of the respondents were from overseas, limited English language proficiency and cultural difference did not appear as the major barriers to communication. It appeared that proper training and adequate opportunities to practice are likely to improve communication skills of the students.

\subsection{Efforts by academic institutions for imparting soft skills}

The students were asked about the avenues and opportunities provided by their respective universities for developing soft skills. Around $54 \%$ of the students said that soft skills were usually embedded in different academic courses. Another $47 \%$ of the students mentioned that they had taken some credit courses that focused on developing certain soft skills. Some examples of such credit courses, as quoted by the students, were: Business Communication, Strategic Management, Leadership and TeamBuilding, Management Communication, Effective Communication, Fundamental Communication, Creative Problem-solving, and Strategic Thinking.

In addition to integrating soft skills in certain professional courses and specialized soft skills development credit courses, the universities of the participating students were also providing many opportunities to their students to improve soft skills. A list of such activities, compiled through discussions with business students and their school administrators, was provided in the questionnaire to allow the respondents to indicate their level of participation in these activities. Table 10 shows that, except for 'students coffee sessions', other programs were 'often' participated by less than $20 \%$ of the students. Most of the programs that could help develop students' soft skills were 'rarely' participated by a majority of the students. It appeared that the students were heavily relying on business professional courses as well as specialized courses designed for improving certain skills and to lesser extent on other soft skills development programs.

Table 10. Participation in soft skills development programs $(n=187)$

\begin{tabular}{|l|c|c|c|}
\hline \multicolumn{1}{|c|}{ Programmes/Activities } & Never & Rarely & Often \\
\hline Workshops/ guest talks & $11.2 \%$ & $70.1 \%$ & $18.7 \%$ \\
\hline Job hunting skills & $18.2 \%$ & $65.8 \%$ & $16.0 \%$ \\
\hline Company orientation sessions & $22.5 \%$ & $58.8 \%$ & $18.7 \%$ \\
\hline Career advising sessions & $27.8 \%$ & $55.6 \%$ & $16.6 \%$ \\
\hline Students coffee sessions & $27.8 \%$ & $49.2 \%$ & $23.0 \%$ \\
\hline
\end{tabular}

In addition, a set of statements were used to capture students' perceptions of the possible benefits of different school-based initiatives in improving their soft skills. These statements presented both positive and negative sides of these programs. More than $61 \%$ of the students either agreed or strongly 
agreed with three statements suggesting that soft skills programs provided them opportunities to gain hands-on experience, boosted their skill levels, and showed ways to apply soft skills in different situations (see Table 11). However, split responses were received for two statements suggesting that content of these soft skills programs were less relevant and cannot be easily applied into practice. More respondents disagreed than agreed with the statement that these programs were only theoretical in nature. In other words they believed that skills taught through these programs had their applicability.

Table 11. Perceptions of the benefits of soft skills programs (multiple responses)

\begin{tabular}{|l|c|c|c|c|c|}
\hline \multicolumn{1}{|c|}{ Statements } & SD & D & N & A & SA \\
\hline $\begin{array}{l}\text { Provided opportunities for } \\
\text { hands-on experience }\end{array}$ & 5 & 5 & 54 & 99 & 24 \\
\hline $\begin{array}{l}\text { Provided me opportunities to } \\
\text { boost my soft skills }\end{array}$ & 6 & 5 & 57 & 85 & 34 \\
\hline $\begin{array}{l}\text { Showed adaptability of soft } \\
\text { skills in many situations }\end{array}$ & 3 & 11 & 59 & 92 & 22 \\
\hline $\begin{array}{l}\text { The contents are not so relevant } \\
\text { with soft skills improvement }\end{array}$ & 7 & 45 & 75 & 53 & 7 \\
\hline $\begin{array}{l}\text { The contents cannot be easily } \\
\text { applied into practice }\end{array}$ & 10 & 42 & 77 & 45 & 12 \\
\hline $\begin{array}{l}\text { Showed the usefulness of soft } \\
\text { skills only in theory }\end{array}$ & 19 & 41 & 74 & 37 & 15 \\
\hline
\end{tabular}

SD: strongly disagree, D: disagree, N: neutral, A: agree, SA: strongly agree

\subsection{Suggestions for improving students' soft skills}

The respondents were asked to suggest measures that universities should undertake for improving soft skills of their students. Over $60 \%$ of the students recommended that more soft skills development activities should be incorporated into the curriculum (see Table 12). Two other measures suggested by around $45 \%$ of the students were to organize more soft skills development workshops and hands-on activities. Once again it appeared that, instead of attending specialized soft skills development workshops, a majority of the students desired that such skills should be embedded in appropriate professional courses.

Table 12. Soft skills development measures to be undertaken taken by universities (multiple responses)

\begin{tabular}{|l|c|}
\hline \multicolumn{1}{|c|}{ Suggested Measures } & Frequency \\
\hline $\begin{array}{l}\text { Incorporate more soft skills development } \\
\text { activities into the curriculum }\end{array}$ & $\mathbf{1 1 4}$ \\
\hline Organize more workshops & 84 \\
\hline Organize more hands-on activities & 81 \\
\hline Arrange more internship programmes & 75 \\
\hline Organize more company orientation talks & 54 \\
\hline
\end{tabular}

In addition, the respondents were asked to suggest measures that students should undertake for improving their soft skills. Nearly one-half of the respondents suggested that students should attend professional training workshops for improving their soft skills (see Table 13). It was also suggested by $42 \%$ of the respondents each that students should join those hobby clubs and students' union activities that can help improve their soft skills.

Table 13. Soft skills development measures to be undertaken by students (multiple responses)

\begin{tabular}{|l|c|}
\hline \multicolumn{1}{|c|}{ Suggested Measures } & Frequency \\
\hline Attend professional training workshops & $\mathbf{9 3}$ \\
\hline $\begin{array}{l}\text { Join hobby clubs providing soft skills } \\
\text { development opportunities }\end{array}$ & 79 \\
\hline $\begin{array}{l}\text { Participate in activities organized by the } \\
\text { student unions }\end{array}$ & 72 \\
\hline $\begin{array}{l}\text { Read books and articles on soft skills-related } \\
\text { topics }\end{array}$ & 70 \\
\hline
\end{tabular}

\section{Conclusion}

The purpose of this study was to investigate students' perceptions of the importance of soft skills for education and employment. The results showed that generally business management students in Singapore were aware of the importance of soft skills for employment and career advancement. However, many students felt that their actual soft skills were less than the desired levels. It was also found that communication skills were perceived to be the least important by the students and probably that is why they did not try to improve these skills. It was a matter of concern as many previous studies, investigating competencies sought after by potential employers, reported that communication skills were among the most desired soft skills. Thus there is need to create awareness among the students about the importance of communication skills for career advancement and how to develop and practice such skills.

Another related finding was that a majority of the students expressed the opinion that soft skills training should be embedded in appropriate business courses. Probably this approach was preferred because it could provide an opportunity to the students to understand how to apply these skills in a specific situation. It is also possible that they feel overloaded with professional courses thus less inclined to attend specialized soft skill development programs organized by their universities. It is, therefore, desirable that business schools as well as other 
schools should carefully review and incorporate the desired soft skills into their curricula. However, they should also continue running specialized training workshops to help students further improve their soft skills. It is equally important that students should also make efforts for improving their skills level through self-directed readings and participation in appropriate skills development programs and activities.

\section{References}

[1] Wats, M., \& Wats, R.K. (2009). Developing soft skills in students. The International Journal of Learning, 15(12), 1-10.

[2] Mitchell, G. W., Skinner, L. B., \& White, B. J. (2010). Essential soft skills for success in the twentyfirst century workforce as perceived by business educators. Delta Pi Epsilon Journal, 52(1), 43-53.

[3] Gupta, Y. (2009). Building a better business student. BizEd, 9(6), 62-63.

[4] Hodges, D., \& Burchell, N. (2003). Business graduate competencies: Employers' views on importance and performance. Asia-Pacific Journal of Cooperative Education, 4(2), 16-22.

[5] Rubin, R.S. (2009). How relevant is the MBA? Assessing the alignment of required curricula and required managerial competencies. Academy of Management Learning \& Education, 8(2), 208-224.

[6] Porter, J. (2007). B-schools soft on 'soft skills'. Bollomberg BusinessWeek Online, http://www. businessweek.com/bschools/content/aug2007/bs2007 082_280172.htm (Access date: December 19, 2011)

[7] Rynes, S. L., Trank, C. Q., Lawson, A. M., \& Ilies, R. (2003). Behavioural coursework in business education: Growing evidence of a legitimacy crisis. Academy of Management Learning \& Education, 2, 269-283.

[8] Kumara, S.A.V., \& Sahasranam, C. (2008). An empirical study on students' soft skills inventory test: Reliability and non-parametric analysis. The Icfai University Journal of Soft Skills, 2(3), 35-45.

[9] Addams, A.L., Woodbury, D., Allred, T., \& Addams, J. (2010). Developing student communication skills while assisting nonprofit organizations. Business Communication Quarterly, 73(3), 282-290.
[10] Alshare, K.A, Lane, P.L., \& Miller, D. (2011). Business communication skills in Information Systems (IS) curricula: Perspectives of IS educators and students. Journal of Education for Business, 86: 186-194.

[11] McEnrue, M. P., Groves, K. S., \& Shen, W. (2009). Emotional intelligence development: Leveraging individual characteristic. The Journal of Management Development, 28(2), 150.

[12] Howe, S. (2010). Can EQ be learned? Fleet Maintenance. Fort Atkinson, 14(10), 36. 